\title{
JUURNAL.RU
}

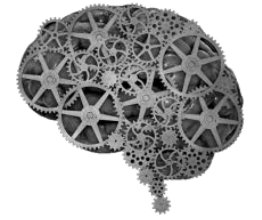

COMPANY GROUP "INTELLEKT"

\author{
Шишкова Ю.С., Липская А.Д. \\ ГБОУ ВПО «Южно-Уральский государственный медицинский университет» \\ Челябинск, Россия
}

doi: 10.18411/lj2016-5-5-17

\section{Влияние акриловой пластмассы на функциональный статус нейтрофилов}

В последние годы неуклонно растет количество пациентов, которые нуждаются в ортопедической стоматологической помощи. Для изготовления большинства съемных зубных протезов используются акриловые пластмассы, благодаря их низкой токсичности, высокой технологичности, ценовой доступности, легкости, надежности, простоте установки и ухода и эстетическим качествам [1]. При этом есть результаты ряда исследований, указывающих на то, что данный материал не является полностью биологически инертным. Детальное изучение реакции врожденного иммунитета на материалы, использующиеся для изготовления съемных пластиночных протезов, является обязательным этапом в понимании механизмов формирования воспаления при использовании съемных зубных протезов $[1,3]$. Научно обоснованное решение вопроса о биологической инертности акриловых пластмасс позволит совершенствовать методы лечения в стоматологической практике [2].

В связи с этим, нами решено было оценить функциональный статус нейтрофилов при встрече с акриловыми пластмассами (in vitro).

Для проведения эксперимента использовались базисная акриловая пластмасса горячей полимеризации и акриловая пластмасса холодной полимеризации, покрытая кобальтохромовым сплавом и нитрид титаном.

Для изучения функционального ответа нейтрофилов, клетки выделяли из лейкоцитарной взвеси крови 20 условно здоровых доноров на двойном 
градиенте плотности стерильных растворов фиколл-верографина и доводили до концентрации 5х106 клеток/мл.

Нейтрофилы активировали базисной акриловой пластмассой горячей полимеризации и акриловой пластмассой холодной полимеризации, покрытой кобальтохромовым сплавом и нитрид титаном. Для контроля использовали нейтрофилы без активации или активированные частицами латекса.

После активации изучали продукцию активных форм кислорода (НСТтест), лизосомальную активность и фагоцитарную функцию. Полученные даны были повергнуты статистической обработке. Вычисляли медиану и квартили.

В результате проведенных исследований нами не обнаружено статистически значимые отличий между показателями лизасомальной активности нейтрофилов без активации и при активации базисной акриловой пластмассой горячей полимеризации. Показатели при активации металлопластмассой были значимо выше, чем акриловой пластмассой (Таблица 1).

Таблииа 1

Показатели лизосомальной активности нейтрофилов в зависимости от вида акриловой пластмассы, Med (25 prc-75prc)

\begin{tabular}{|c|l|l|}
\hline & & \multicolumn{1}{|c|}{ Активность лизосом, \% } \\
\hline Без активации (n=20) & 1 & $21,95(15,00-38,50)$ \\
\hline Базисная акриловая пластмасса горячей полимеризации (n=10) & 2 & $24,00(17,00-49,50)$ \\
\hline $\begin{array}{c}\text { Акриловая пластмасса холодной полимеризации, покрытая } \\
\text { кобальтохромовым сплавом и нитрид титаном (n=10) }\end{array}$ & 3 & $34,00(33,5-70,00)$ \\
\cline { 3 - 4 } & $\mathrm{P}_{2-3}=0,04$ \\
\hline
\end{tabular}

Активность НСТ - реакции нейтрофилов статистически значимо не отличалась при спонтанной реакции, при индуцировании базисной акриловой пластмассой горячей полимеризации и при активации акриловой пластмассой холодной полимеризации, покрытой кобальтохромовым сплавом и нитрид титаном.

При изучение фагоцитарной способности нейтрофилов при активации их разными видами акриловой пластмассы статистически значимых отличий с сравниваемых группах получено не было. Активность фагоцитоза была статистически значимо выше при взаимодействии нейтрофилов с базисной 
акриловой пластмассой горячей полимеризации, чем при активации латексом. При этом интенсивность фагоцитоза была значимо выше при активации нейтрофилов акриловой пластмассой холодной полимеризации, покрытой кобальтохромовым сплавом и нитрид титаном по сравнению с показателями при активации латексом. Результаты исследования представлены в таблице 2.

Таблииа 2

Показатели фагоцитарной способности нейтрофилов в зависимости от вида акриловой

\begin{tabular}{|c|c|c|c|}
\hline & & \multicolumn{2}{|c|}{ Показатели фагоцитоза } \\
\hline & & $\begin{array}{c}\text { Активность фагоцитоза, } \\
\%\end{array}$ & $\begin{array}{c}\text { Интенсивность фагоцитоза, } \\
\text { усл.ед. }\end{array}$ \\
\hline Латекс $(n=20)$ & 1 & $35,73(22,75-53,53)$ & $1,81(1,18-2,28)$ \\
\hline \multirow{2}{*}{$\begin{array}{c}\text { Базисная акриловая пластмасса горячей } \\
\text { полимеризации }(\mathrm{n}=10)\end{array}$} & \multirow[t]{2}{*}{2} & $79,40(31,28-91,83)$ & $2,37(0,69-6,69)$ \\
\hline & & $\mathrm{p}_{1-2}=0,03$ & \\
\hline \multirow{2}{*}{$\begin{array}{c}\text { Акриловая пластмасса холодной } \\
\text { полимеризации, покрытая } \\
\text { кобальтохромовым сплавом и нитрид } \\
\text { титаном }(\mathrm{n}=10)\end{array}$} & \multirow[t]{2}{*}{3} & $46,71(34,30-76,57)$ & $2,43(1,88-2,90)$ \\
\hline & & & $\mathrm{p}_{1-3}=0,01$ \\
\hline
\end{tabular}

Таким образом, вне зависимости от вида акриловой пластмассы она практически не оказывает влияния на функциональный статус нейтрофильных гранулоцитов, выделенных из периферической крови.

Таким образом, сам материал является инертным по отношению к нейтрофилам. На основе полученных результатах можно сделать выводы, что именно микроорганизмы, заселяющие протез, оказывают негативное действие на гомеостаз ротовой полости. 


\section{Литература:}

1. Дубова, Л. Выявление реакции гиперчувствительности к акриловым пластмассам in vivo и in vitro / Л. Дубова. - Cathedra - кафедра. Стоматологическое образование. 2011. № 38. С. 26-29.

2. Дятленко, К.А. Выбор базисного материала при протезировании лиц пожилого возраста частичными съемными протезами / К.А. Дятленко, А.О. Деревянченко, Ю.О. Колесова. - Электронный научнообразовательный вестник Здоровье и образование в XXI веке. 2012. Т. 14.№ 7. C. 124-125.

3. Романова, Ю.Г. Частота проявления аллергических реакций в полости рта на акриловые пластмассы / Ю.Г. Романова, В.В. Лепский, О.И. Жижикин. Вестник стоматологии. 2011. № 2 (75). С. 78-80.Василенко А.А., Герасимов С.В., Денисов Д.С., Кривенцов Н.М., Поршнев А.В., Пичхидзе С.Я., Нечаев Г.Г. Характеристики покрытий, полученных методом МДО в электролите-суспензии. Саратов: СГТУ. 2015.-4c. 